\title{
HYPOLIPIDEMIC EFFECTS OF GARLIC EXTRACTS IN HIGH FAT HIGH CHOLESTEROL DIET FED RATS
}

Sunanda Murthy ${ }^{1}$, Kanthaiah², Govindaswamy ${ }^{3}$

\section{HOW TO CITE THIS ARTICLE:}

Sunanda Murthy, Kanthaiah, Govindaswamy. "Hypolipidemic Effects of Garlic Extracts in High Fat High Cholesterol Diet Fed Rats". Journal of Evolution of Medical and Dental Sciences 2014; Vol. 3, Issue 06, February 10; Page: 1334-1338, DOI: 10.14260/jemds/2014/1988

ABSTRACT: Garlic is used widely in food and pharmaceutical preparations in India. The hypolipidemic, anti-atherosclerotic as well fibrinolytic properties of garlic sulphur compounds are known since long time. This principle sulphur compound present in garlic extract and garlic oil is Diallyldisulphide (DADS) an unsaturated aliphatic disulphide, which is thought to be mainly responsible for garlic beneficial effects. The present work was under taken to assess usefulness and toxic effects of the garlic extracts in high lipid diet (HLD) fed rats. It is evident from results that garlic aqueous extracts have hypolipidemic effects in plasma and fatty changes in liver in high lipid diet rats. These hypolipidemic effects of garlic aqueous extracts may be due to its principle sulfur compound DADS.

KEYWORDS: Garlic, Cholesterol, lipid profile, lipotropic factors, DADS.

INTRODUCTION: Augusti and Mathew ${ }^{1}$ first reported that an aqueous extract of garlic has hypolipidemic action on normal rats. Gebhardt ${ }^{2}$ found that culture of rat hepatocytes on incubation with water soluble extracts of garlic powder diminished cholesterol biosynthesis and its export in to the medium. HMG COA reductase activity is significantly inhibited by garlic extracts DADS, a component of garlic extract Bordia and Verma ${ }^{3}$ reported that supplementation of garlic to rabbits fed with a hypercholesteremic diet showed significant decrease in LDL and VLDL and significant increase in HDL levels. On continued garlic consumption, the excess lipids were broken down and finally excreted from the body. Several animal studies have demonstrated that components of garlic inhibit synthesis by liver cells ${ }^{4}, 5$. On feeding garlic extracts to rats decreased the activity of several important enzymes involved in the synthesis of lipids not only in the liver but also in adipose tissues such as fat pads $^{6}$. Study was under taken to assess usefulness of the garlic extracts in high lipid diet fed rats (HLD).

MATERIALS AND METHOD: This work was conducted at Department of Biochemistry, Animal house of Dr. B.R. Ambedkar Medical College upon approval of the committee of ethics in animal experimentation (132/1999/CPCSEA). All the chemicals and reagents were of Analar Grade, supplied by various companies like, British Drug house Glaxo laboratories E. Merck, London and Sigma Aldrich holding compound.

\section{Preparation of garlic extracts:}

Aqueous extract of garlic (AEG): Fresh garlic bulbs were crushed to get a fine paste in waring blender with equal volume of water. The mixture was filtered through gauze cloth. The filtrate was used to feed rats, one $\mathrm{ml}$ of this extract was considered to be equivalent to $500 \mathrm{mg}$ of garlic. Aqueous extract principally contains sulphoxide mainly cysteine sulphoxide $\mathrm{e}^{7}$. This was prepared fresh daily. 
An optimum dose of $3 \mathrm{~g} / \mathrm{kg}$ body weight was employed in this study. This $3 \mathrm{~g}$ optimum dosage was arrived at as a result of previous experiments conducted in our lab.

Methanol Hexane extract of garlic (HEG): Garlic was homogenized in enough methanol and was kept overnight at room temperature. Methanol soluble was separated by filtration. This process was repeated for three times with the residue. All methanol soluble fractions were pooled and methanol was distilled off, the left over residue was extracted with diethyl ether for three times. Ether was distilled off and left over oil was dissolved in methanol and stored for four days at $25^{\circ} \mathrm{C}$. It was then extracted with hexane and hexane was distilled off. Hexane soluble fraction was stored which contains several sulphur compounds and principle sulphur compound is DADS7

High lipid high cholesterol diet (HLD):High lipid high cholesterol diet was prepared by mixing whole milk powder, dalda and cholesterol in the proportion of 1.0: $0.5: 0.1(\mathrm{w} / \mathrm{w})$ with necessary vitamin supplements; $1.2 \mathrm{mg}$ thiamine, $2 \mathrm{mg}$ riboflavin and $3 \mathrm{mg}$ niacin per 100gm HLD. This was prepared fresh every day.

Experimental animals: Healthy inbred adult male albino rats of 2-3 months old weighing 100$150 \mathrm{gm}$ were selected from the animal house of Dr. B.R. Ambedkar Medical College, Bangalore. They were fed with Amruth Rat Feed Nava Maharashtra Chakan oil Ltd Pune adlibitum, unless otherwise stated. Water was given adlibitum.

Experimental groups: For the present study rats were divided into 4 groups, consisting of 6 rats in each group.

Group-1 Normal group: Consists of six rats fed stock lab diet and were given $30 \mathrm{ml}$ normal saline per kg body wt. intragastrically using stomach tube for 60 days.

Group-2 control group: Consists of six rats fed with HLD and given $30 \mathrm{ml}$ saline per kg body wt instragastrically using stomach tube for 60 days.

Group-3 AEG fed group: Consists of six rats fed with HLD and were given 3gm of AEG in 30ml normal saline per kg body wt. intragastrically using stomach tube for 60 days.

Group-4 HEG fed group: Consists of six rats fed with HLD and were given 0.2gm HEG in 30ml normal saline per kg body weight intragastrically using stomach tube for 60 days. After 60 days the rats of group 1-4 were sacrificed by decapitation. Blood was collected using heparin as an anti-coagulant. Plasma were analyzed for total lipid [TL $]^{8}$, total cholesterol $[\mathrm{TC}]^{9}$, triacylglycerol $[\mathrm{TAG}]^{10}$, phospholipid [PL], esterified fatty acid (EFA), free fatty acid (FFA) ${ }^{11}$.

Liver was collected into ice cold containers and processed immediately.

A part of liver was homogenized in chloroform-methanol 1:1 (v/v) and extract was used for TL, TC, TAG, PL.

Another part of the liver was homogenized in 5\% cold TCA and was used to estimate thiobarbutric acid reactive substance (TBARS) ${ }^{12}$.

A part of liver was selected and collected in buffered formalin and used for histomorphological studies.

RESULTS: Results obtained in the present study are given in table. 
DISCUSSION: The sulphur compounds sulphoxides and disulphides of garlic extract and oil are known to have hypolipidemic and hypercholesterolemic effects. These effects are more pronounced with garlic oil. The principle sulphur compound of garlic oil is DADS ${ }^{13}$. As seen from the results given in Table, feeding HLD to rats led to elevation of plasma lipid as well as liver tissue lipid levels as compared to normal group. When AEG or HEG is fed to the rats along with HLD a significant decrease is observed in plasma as well as liver tissue lipid levels as compared to control group. This reduction is probably due to the sulphur compound present in garlic DADS 13 , a principal sulphur compound of garlic oil. DADS is known to decrease plasma and liver tissue lipid levels, as it inhibits the enzymes Acetyl COA carboxylase and HMG COA reductase. This action of DADS, may be due to its capacity to reduce cellular NADH / NADPH as the breakdown of DADS requires NADH / NADPH. Such a reduction in NADH /NADPH decreases the fatty acid and cholesterol synthesis as their synthesis requires NADPH. It undergoes exchange reaction with -SH group containing compounds in the body. The decrease in dietary hyperlipemia may partly be due to lipotropic effects of garlic extracts, as evident from rise in FFA in treated rats as compared to control group of rats. The rise in oxygen derived free radicals as evidenced by steep rise in liver TBARS levels and also by the histomorphological studies could be responsible for fatty liver in HLD fed rats ${ }^{14}$.There is not much change in the extract treated group of rats. This shows the toxic effect of garlic.

CONCLUSIONS: Thus it can be concluded that hypolipidemic effects of garlic extracts (both AEG and HEG) and DADS may be due to the unsaturated nature of aliphatic disulphide. The toxic effects are due to the production of acrolein produced from the allyl side chains of this aliphatic disulphide.

\section{REFERENCE:}

1. Augusti K.T and Mathew P.T (1973).Ind J Expt Biol. 11 239-241. Quoted by Shoetan A, Augusti K.T and Joseph P. K (1984). Hypolipidemic effects of garlic oil in rats fed ethanol and a high lipid diet. Experientia 40 261-263.

2. Kashinath R. T. Hypolipidemic effects of disulphide in rats fed high lipid diet and or ethanol. Thesis submitted to Bangalore University pp 167-170(1993).

3. Bordia A. Atherosclerosis, 30 (1978) 355. and Bordia A. and Verma S.K. Artery 7(1980) 428.

4. Sodimu 0, Joseph PK and Augusti KT. Certain biochemical effects of garlic oil in rats maintained on high fat high cholesterol diet. Experentia . 40:78-80:1984.

5. Stevinson C, Pittler MH and Ernst E. Garlic for treating Hypercholesterolemia. Ann. Intern Med. 133, pp. 420-429.20. Lawson L D. (1998).

6. Yu-Yan Yeh, Lijuan Liu. Cholesterol lowering effects of garlic extracts and Orgarnosulphur compounds; Human and Animal studies. The journal of nutrition 2001; 131(3) 9895-9935.

7. Raghavan B, Abrahan KO and Shankaranarayana ML. Chemistry of garlic and garlic products. Biochem Rev42:1-9, 1982.

8. Chaudhary K. in Biochemical techniques, Jaypee Bros. New-Delhi ,pp 112-114 1989

9. Varley H. Lipids and lipoproteins, Chapter 21 in Practical Clinical Biochemisty. Varley H, Allan H.G, Maurice B. (Edn) London, Heineman professional publishing Ltd, 625-685,1980.

10. Henry R. J, Connan D.C and Wickelman J. W. in "Clinical Chemistry Principles and Practice" $2^{\text {nd }}$ Edn. 1974, pp-1456-1460.Harper-Row Publishers. New York. 
11. Nath R.L. Tests for lipid metabolism in Practice of Biochemistry in clinical Medicine, $2^{\text {ndEdn., }}$ Academic Publishers. Calcutta , India, 112-136, 1990.

12. Nadiger H.A, Marcus S.R., Chandrakala MV and Kulkarni D.D. Malonyldialdehyde levels in different organs of rats subjected to acute alcohol toxicity. Ind J Clin Biochem 1,133-136,1986.

13. Shoetan A, Augusti K. T and Joseph P.K. "Hypolipidemic effect of garlic oil rats fed ethanol and high lipid diet". Experiment 1984; 40,261-263.

14. Sheela CG, Augusti K.T. Antiperoxide effects of S-allyl cysteine sulphoxide isolated from allium sativumlinn and gugulipid in cholesterol diet fed rats. Indian Journal of Experimental Biology 33;337-341;1995.

\begin{tabular}{|c|c|c|c|c|}
\hline Parameter & $\begin{array}{l}\text { Group } 1 \\
\text { Normal }\end{array}$ & $\begin{array}{l}\text { Group } 2 \\
\text { Control }\end{array}$ & $\begin{array}{l}\text { Group } 3 \\
\text { AEG fed }\end{array}$ & $\begin{array}{l}\text { Group } 4 \\
\text { HEG fed }\end{array}$ \\
\hline $\begin{array}{c}\text { Plasma mg\% } \\
\text { TL }\end{array}$ & $338.57 \pm 41.47$ & $1397 \pm 46.93 .97$ & $516.3 \pm 44.97$ & $515.3 \pm 31.26$ \\
\hline Liver g/g & $45.2 \pm 3.34$ & $87.9 \pm 9.44$ & $76.68 \pm 7.59$ & $77.93 \pm 5.38$ \\
\hline $\begin{array}{c}\text { Plasma mg\% } \\
\text { TC }\end{array}$ & $142.8 \pm 21.52$ & $300.6 \pm 14.97$ & $167.2 \pm 6.34$ & $168.2 \pm 6.2$ \\
\hline Liver g/g & $6.1 \pm 0.58$ & $10.34 \pm 0.064$ & $8.86 \pm 0.59$ & $7.73 \pm 0.77$ \\
\hline $\begin{array}{c}\text { Plasma mg\% } \\
\text { TAG }\end{array}$ & $114.27 \pm 28.53$ & $338.8 \pm 10.26$ & $192.98 \pm 18.27$ & $187.6 \pm 15.84$ \\
\hline Liver g/g & $72.8 \pm 3.25$ & $124.4 \pm 5.61$ & $86.75 \pm 3.92$ & $86.27 \pm 7.56$ \\
\hline $\begin{array}{c}\text { Plasma mg\% } \\
\text { PL }\end{array}$ & $18.95 \pm 1.32$ & $20.7 \pm 0.769$ & $18.74 \pm 1.46$ & $19.21 \pm 1.6$ \\
\hline Liver g/g & $18.95 \pm 1.32$ & $20.68 \pm 0.77$ & $1749 \pm 1.61$ & $18.99 \pm 1.71$ \\
\hline EFA mg\% & $445 \pm 40.30$ & $650.8 \pm 70.65$ & $552.8 \pm 37.10$ & $534.13 \pm 27.65$ \\
\hline $\begin{array}{c}\text { FFAMeq/L } \\
\text { Liver }\end{array}$ & $0.525 \pm 0.065$ & $0.41 \pm 0.051$ & $0.82 \pm 0.0992$ & $0.8 \pm 0.07$ \\
\hline TBARS micro g/gm & 3.01 & 5.61 & 5.72 & 6.38 \\
\hline
\end{tabular}




\section{ORIGINAL ARTICLE}

\section{AUTHORS:}

1. Sunanda Murthy

2. Kanthaiah

3. Govindaswamy

\section{PARTICULARS OF CONTRIBUTORS:}

1. Associate Professor, Department of Biochemistry, Dr. B. R. Ambedkar Medical College, K.G. Halli, Bangalore.

2. Associate Professor, Department of Biochemistry, Hassan Institute of Medical Sciences, Hassan, India.

3. Associate Professor, Department of Biochemistry, Shimoga Institute of Medical Sciences, Shivmoga, India.

\section{NAME ADDRESS EMAIL ID OF THE CORRESPONDING AUTHOR:}

Dr. Sunanda Murthy, Department of Biochemistry, Dr. B. R. Ambedkar Medical College, K. G. Halli, Bangalore.

E-mail: kanthaiahm@rediffmail.com ksgovindaswamy@rediffmail.com

Date of Submission: 08/01/2014. Date of Peer Review: 09/01/2014. Date of Acceptance: 24/01/2014. Date of Publishing: 04/01/2014. 